\title{
Heavy Metals Affect Nematocysts Discharge Response and Biological Activity of Crude Venom in the Jellyfish Pelagia noctiluca (Cnidaria, Scyphozoa)
}

\author{
Rossana Morabito $^{a}$ Silvia Dossena ${ }^{b}$ Giuseppa La Spadac Angela Marinoc

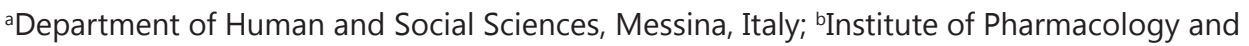 \\ Toxicology, Paracelsus Medizinische Privatuniversität, Salzburg, Austria; 'Department of Biological and \\ Environmental Sciences, Messina, Italy
}

\section{Key Words}

Heavy metals $•$ Nematocysts $•$ Discharge $・$ Crude venom $\bullet$ Jellyfish $•$ Pelagia noctiluca

\begin{abstract}
Background: Pollution of marine ecosystems and, specifically, heavy metals contamination may compromise the physiology of marine animals with events occurring on a cellular and molecular level. The present study focuses on the effect of short-term exposure to heavy metals like Zinc, Cadmium, Cobalt and Lanthanum (2-10 mM) on the homeostasis of Pelagia noctiluca (Cnidaria, Scyphozoa), a jellyfish abundant in the Mediterranean sea. This species possesses stinging organoids, termed nematocysts, whose discharge and concomitant delivery of venom underlie the survival of all Cnidaria. Methods: Nematocysts discharge response, elicited by combined chemico-physical stimulation, was verified on excised oral arms exposed to heavy metals for $20 \mathrm{~min}$. In addition, the hemolytic activity of toxins, contained in the crude venom extracted from nematocysts isolated from oral arms, was tested on human erythrocytes, in the presence of heavy metals or their mixture. Results: Treatment with heavy metals significantly inhibited both nematocysts discharge response and hemolytic activity of crude venom, in a dose-dependent manner, not involving oxidative events, that was irreversible in the case of Lanthanum. Conclusion: Our findings show that the homeostasis of Pelagia noctiluca, in terms of nematocysts discharge capability and effectiveness of venom toxins, is dramatically and rapidly compromised by heavy metals and confirm that this jellyfish is eligible as a model for ecotoxicological investigations.
\end{abstract}




\section{Introduction}

Cnidaria, representing the first stage of Metazoan evolution, comprise different classes, such as Anthozoa, Scyphozoa, Hydrozoa and Cubozoa, all worldwide distributed and possessing highly specialized stinging cells, referred to as nematocytes. These cells produce an organoid, the nematocyst, which occupies most of the cytoplasm and consists of a large capsular structure with a spiny tubule inside, immersed in the crude venom - a fluid matrix containing toxins $[1,2]$. When an appropriate chemico-physical stimulus is applied, both tubule and toxins are promptly delivered via an exocytotic process termed discharge. Discharge is one of the most rapid biological responses known so far, whose activation mechanism has been focused on by many authors [2-5]. The first stage for discharge activation is chemosensitization, occurring via binding of exogenous compounds to chemoreceptors located on cells, other than nematocytes, modulating in turn the mechanosensitive apparatus (cilia). Contact with the prey and release of substances from its tissues further activates the process [6-9]. Therefore, discharge is reasonably acknowledged as the physiologic reaction responsible for Cnidaria survival through the ages, since it is used for either prey capture or defensive and locomotory functions $[10,11]$.

As already mentioned, discharge response is strictly associated with toxins release, being the crude venom delivered as a consequence of the ejection of the inverted tubule contained in the nematocyst. Crude venom from different Cnidaria specimens is reported to contain diverse compounds showing hemolytic, cytolytic, clastogenic, enzymatic, cardiotoxic, neurotoxic and even insecticidal effects, as revealed by different biological assays [12-18]. However, the current understanding on Cnidaria venom composition and biological activity is still incomplete for many species.

With regard to discharge response and biological activity of crude venom in the jellyfish Pelagia noctiluca, several investigations added novel contribution to the understanding of the physiology of this Cnidarian [4, 5, 19-27]. The current knowledge of Pelagia noctiluca biology $[17,28]$ and physiology $[5,29,30]$ may allow to propose this specimen and its homeostatic features as new models to monitor the possible presence and ecological impact of marine pollutants, such as hydrocharbons and heavy metals, and ocean acidification. Concerning this latter phenomenon, it has been recently proven that acidification of the external medium significantly impairs discharge response and cell volume regulation capability following hypotonic shock (regulatory volume decrease, RVD) [20] of Pelagia noctiluca nematocytes. Moreover, in the same species, RVD is also inhibited by heavy metals such as cadmium, zinc and cobalt [19].

Pelagia noctiluca specimens are particularly abundant in the Mediterranean sea [31], especially in the Strait of Messina, an exemplary habitat where anthropic factors may critically contribute to pollution, including heavy metals contamination. Therefore, the aim of the present investigation was to verify the effect of heavy metals on Pelagia noctiluca homeostasis, with specific regard to discharge response and hemolytic power of crude venom. With this purpose, holotrichous isorhiza [32] nematocysts discharge has been studied on isolated oral arms, according to the Thorington and Hessinger [33] and Morabito et al. [5] technique. The biologic activity of toxins contained in the crude venom was assessed via an hemolytic assay on human erythrocytes, according to Marino et al. [21, 22].

\section{Materials and Methods}

\section{Specimens collection}

Specimens of Pelagia noctiluca (Cnidaria, Scyphozoa) were collected during Summer 2013 in the Strait of Messina (Italy) and immediately used for experiments. Oral arms were utilized for experiments evaluating nematocysts discharge and crude venom extraction.

In situ discharge

Segments of oral arms, approximately of the same size, were excised with ophthalmic scissors and collected by fire-polished silicon-coated Pasteur pipettes. Segments were then rinsed with low-Ca ${ }^{2+}$ artificial 
sea water (ASW, in mM: $\mathrm{NaCl} 520, \mathrm{KCl} 9.7, \mathrm{CaCl}_{2} 0.01, \mathrm{MgCl}_{2} 24, \mathrm{MgSO}_{4} 28$, imidazole 5, pH=7.65, 1100 $\mathrm{mOsm} / \mathrm{Kg}_{\text {нго }}$ ) to remove mucus. Tissues were then transferred into $5 \mathrm{ml}$ Petri dishes previously treated with Sylgard (Dow Corning), fixed with Opuntia spines and repeatedly rinsed with standard ASW (in mM: $\mathrm{NaCl} 520, \mathrm{KCl} 9.7, \mathrm{CaCl}_{2} 10, \mathrm{MgCl}_{2} 24, \mathrm{MgSO}_{4} 28$, imidazole 5, $\mathrm{pH} 7.65 ; 1100 \mathrm{mOsm} / \mathrm{Kg}_{\mathrm{H} 20}$ ). Oral arms were carefully checked under a light microscope (100x magnification) to assess their structural integrity and then submitted to a combined chemical-mechanical stimulation, as described in the following.

Control experiments. Nematocysts discharge was elicited in situ by combined chemical-mechanical stimulation of oral arms, accordingly to Thorington and Hessinger [33] and Morabito et al. [5]. Glutamate was chosen as the chemosensitizer compound [5]. The chemical-mechanical stimulation consisted in a $20 \mathrm{~min}$ incubation of the oral arms in $5 \mathrm{ml}$ standard ASW plus $10^{-3} \mathrm{M}$ glutamate (chemosensitization), followed by mechanical stimulation with a gelatine-coated non-vibrating test probe. Test probes consisted of $2 \mathrm{~cm}$ segments of $0.8 \pm 0.01 \mathrm{~mm}$ diameter nylon fishing line coated at one end with $30 \%(\mathrm{w} / \mathrm{v})$ gelatine with a thickness of approximately $0.06 \mathrm{~mm}$. After storage for $24 \mathrm{~h}$ at $4{ }^{\circ} \mathrm{C}$ and $100 \%$ humidity, the probes were inserted, at the uncoated end, into glass capillary tubes and fixed to a micromanipulator (Leitz). Test probes were then moved into the tissue by careful checking with an inverted microscope (Zeiss, 200x magnification). This manoeuvre induced nematocysts discharge and allowed for the adhesion of fired capsules to the gelatine. The individual gelatine-coated probes, possibly bearing fired nematocysts, were placed in separate microtiter wells (Microtest 11, Falcon Plastics) each containing $50 \mu \mathrm{L}$ of $1 \%$ enzyme/ detergent mixture (Trizyme; Amway Products, Ada, MI, USA). After a $4 \mathrm{~h}$ incubation at room temperature the gelatine was completely dissolved and probes were discarded. Discharged nematocysts were counted by inspecting with an inverted microscope (Zeiss, 400x magnification) and their number (nematocysts/probe) was considered as an index for discharge response.

Evaluation of the effect of heavy metals on nematocysts discharge. To test for a possible modulation of in situ discharge following exposure to heavy metals, oral arms were incubated for $20 \mathrm{~min}$ in $5 \mathrm{ml}$ standard ASW containing $2 \mathrm{mM} \mathrm{ZnCl}_{2}, \mathrm{CdSO}_{4}, \mathrm{CoCl}_{2}$ or $\mathrm{La}\left(\mathrm{NO}_{3}\right)_{3}$. After incubation, the ASW containing heavy metals was removed and chemical-mechanical stimulation immediately followed as previously described. To exclude a possible direct discharge-inducing effect of heavy metals on oral arms, the latter were exposed to heavy metals and then mechanically stimulated by the non-vibrating test probe, without previous chemosensitization with glutamate. Discharge response was then evaluated as reported previously.

\section{Nematocysts isolation and crude venom extraction}

In order to perform the hemolytic assay, it was firstly necessary to isolate nematocysts from oral arms of the collected jellyfish [29] and then extract the crude venom [21].

The oral arms were excised and submerged in distilled water for $2 \mathrm{~h}$ at $4{ }^{\circ} \mathrm{C}$. In these conditions, undischarged nematocysts are released following osmotic lysis of nematocytes. After a complete detachment of the epidermis, the underlying tissue was removed from the suspension containing both the epidermis and nematocysts. Further release of nematocysts still attached to the epidermal tissue was induced by stirring. The nematocysts were repeatedly washed in distilled water and filtered through plankton nets $(100,60$ and $40 \mu \mathrm{m}$ mesh nets were used in this order) to remove most of the tissue debris, and then centrifuged at $4{ }^{\circ} \mathrm{C}$ (ALC PK 120R centrifuge, $4000 \mathrm{~g}$ for $5 \mathrm{~min}$ ). The suspension was immediately used or, alternatively, frozen at $-20^{\circ} \mathrm{C}$ until use. The nematocysts obtained with this method were classified as holotrichous isorhizas, according to Mariscal [32].

The nematocysts were defrosted, filtered and washed again in distilled water before each experiment. Nematocysts were then re-suspended in $0.01 \mathrm{M}$ phosphate buffer containing $0.9 \% \mathrm{NaCl}(\mathrm{pH} 7.4,300 \mathrm{mOsm} /$ $\mathrm{Kg}_{\mathrm{H} 20}$ ). Crude venom was extracted by sonicating (Sonoplus, $70 \mathrm{mHz}, 30$ times, $20 \mathrm{~s}$ ) on ice a suspension of 90 nematocysts $/ \mu \mathrm{L}$. After sonication, the crude venom extract was separated from crushed capsules by centrifugation $\left(4^{\circ} \mathrm{C}, 4000 \mathrm{~g}, 10 \mathrm{~min}\right)$ and used for the hemolytic assay.

\section{Hemolytic assay}

Control experiments. After obtaining informed consent from human healthy volunteers, erythrocytes were prepared by washing fresh human whole blood thrice with $0.01 \mathrm{M}$ phosphate buffer containing $0.9 \%$ $\mathrm{NaCl}, \mathrm{pH}=7.4,300 \mathrm{mOsm} / \mathrm{kg}_{\mathrm{H} 20}$. The erythrocyte suspension $(0.05 \%$ in $0.01 \mathrm{M}$ phosphate buffer containing $0.9 \% \mathrm{NaCl}, \mathrm{pH}=7.4,300 \mathrm{mOsm} / \mathrm{kg}_{\mathrm{H} 20}$ ) was incubated with $5 \%, 10 \%$ or $20 \% \mathrm{v} / \mathrm{v}$ crude venom at $37^{\circ} \mathrm{C}$ for 1 $\mathrm{h}$ and then centrifuged at $2000 \mathrm{~g}$ for $5 \mathrm{~min}$ to precipitate both intact erythrocytes and ghosts. Aliquots of the 
supernatants were then taken and the optical density at $\lambda=414 \mathrm{~nm}$ was spectrophotometrically determined to assess the amount of hemoglobin released from the lysed erythrocytes. The lytic power of the venom was expressed as \% absorbance compared to that observed after maximal lysis of erythrocytes suspended in distilled water. The supernatant of an untreated $0.05 \%$ erythrocytes suspension in isotonic buffer was taken as the negative control.

Evaluation of the effect of heavy metals and their mixture on the hemolytic power of crude venom. The effect of heavy metals on the hemolytic power of crude venom was determined after simultaneously adding either 2, 5 or $10 \mathrm{mM} \mathrm{ZnCl}_{2}, \mathrm{CdSO}_{4}, \mathrm{CoCl}_{2}$, or $\mathrm{La}\left(\mathrm{NO}_{3}\right)_{3}$ and $10 \%$ or $20 \% \mathrm{v} / \mathrm{v}$ crude venom to $0.05 \%$ erythrocytes suspensions for $1 \mathrm{~h}$. The $10 \%$ or $20 \% \mathrm{v} / \mathrm{v}$ crude venom concentrations were chosen as they were particularly effective in inducing hemolysis in control experiments. A similar protocol was applied to test the effect of the heavy metals mixtures on the hemolytic power of crude venom (total concentration: 1-10 $\mathrm{mM}$; the individual heavy metals were present in equimolar amounts). The hemolytic activity of the crude venom was then assayed as described above. To exclude a possible direct hemolytic effect of heavy metals or their mixture, they were prior tested on $0.05 \%$ erythrocytes suspensions, without exposure to crude venom. Hemolysis was then spectrophotometrically determined, as described above.

\section{Salts and chemicals}

Stock solutions (1 M) were prepared dissolving heavy metals salts in distilled water. All salts and chemicals were pro analysis grade and purchased from Sigma (Milan, Italy).

Statistics

Data are shown as mean values \pm standard error of the mean (s.e.m.). $\mathrm{n}$ values represent the number of independent experiments. With regard to discharge experiments, each data set is derived from 20 independent experimental sessions each including 2 oral arms (overall, 40 oral arms isolated from 10 animals collected in the same week were used for each condition tested). With regard to the hemolytic assay, each data set is derived from at least 20 independent experiments each performed on an individual blood sample (overall, 20 blood samples from 20 unrelated donors were used for each condition tested). Significance of the differences between mean values was tested using the one-way analysis of variance (ANOVA), followed by Bonferroni's or Dunnet's post hoc test. $\mathrm{p}<0.05$ was considered as statistically significant.

\section{Results}

Heavy metals significantly reduce in situ nematocysts discharge response in Pelagia noctiluca oral arms

Simple mechanical stimulation of untreated oral arms with a non-vibrating test probe, without prior chemosensitization with glutamate, induced a very low nematocysts discharge (control, $6.87 \pm 0.75$ nematocysts/probe, Fig. 1). Combined chemical-mechanical stimulation of oral arms by incubation with the chemosensitizing compound glutamate $\left(10^{-3} \mathrm{M}\right)$, followed by mechanical stimulation with a non-vibrating test probe, elicited a discharge response significantly higher if compared to that elicited by simple mechanical stimulation (Glut, $39.72 \pm 0.82$ nematocysts/probe, $\mathrm{p}<0.001$, Fig. 1). Treatment of oral arms for 20 min with 2 $\mathrm{mM}$ heavy metals salts followed by combined chemical-mechanical stimulation (incubation with $10^{-3} \mathrm{M}$ glutamate, followed by mechanical stimulation) induced a significant reduction in discharge response compared to untreated oral arms (nematocysts/probe: $\mathrm{ZnCl}_{2} 31.43$ $\pm 0.70, \mathrm{CdSO}_{4} 15.37 \pm 2.12, \mathrm{CoCl}_{2} 21.80 \pm 0.94, \mathrm{La}\left(\mathrm{NO}_{3}\right)_{3} 15.46 \pm 0.04 ; \mathrm{p}<0.001$, Fig.1). In all the conditions tested, discharge determined after heavy metals incubation was significantly higher than in control conditions, i.e. after simple mechanical stimulation $(\mathrm{p}<0.001$, Fig. 1).

To test for the possible reversibility of the inhibitory effect of heavy metals on nematocysts discharge, $\mathrm{ZnCl}_{2}-\mathrm{CdSO}_{4}-, \mathrm{CoCl}_{2}-$ and $\mathrm{La}\left(\mathrm{NO}_{3}\right)_{3}$-treated oral arms were rinsed with standard ASW for 20 min before glutamate exposure and mechanical stimulation by the non-vibrating test probe. In this case, discharge response was recovered, reaching values comparable to those observed in the same experimental conditions without prior exposure to heavy metals (nematocysts/probe: $\mathrm{ZnCl}_{2} 44.24 \pm 1.70, \mathrm{CoCl}_{2} 45.92 \pm 1.85, \mathrm{CdSO}_{4} 44.35 \pm$ 
Fig. 1. Number of nematocysts discharged following a simple mechanical stimulus (control) and after combined chemical-mechanical stimulation consisting in an incubation of oral arms with $10^{-3} \mathrm{M}$ glutamate (Glut) followed by stimulation with a non-vibrating probe, without or with pre-treatment with 2 $\mathrm{mM} \mathrm{ZnCl}_{2}, 2 \mathrm{mM} \mathrm{CdSO}_{4}, 2 \mathrm{mM} \mathrm{CoCl}$ or $2 \mathrm{mM} \mathrm{La}\left(\mathrm{NO}_{3}\right)_{3}$. \#\#\# $\mathrm{p}<0.001$ vs control, $* * * \mathrm{p}<0.001$ vs glutamate and control, $\mathrm{n}=20$.

Fig. 2. Number of discharged nematocysts following a simple mechanical stimulus (control) and after combined chemical-mechanical stimulation consisting in an incubation of oral arms with $10^{-3} \mathrm{M}$ glutamate (Glut) followed by stimulation with a non-vibrating probe, without or with pre-treatment with $2 \mathrm{mM}$ $\mathrm{ZnCl}_{2}, 2 \mathrm{mM} \mathrm{CoCl}_{2}, 2 \mathrm{mM} \mathrm{CdSO}{ }_{4}, 2 \mathrm{mM}$ $\mathrm{La}\left(\mathrm{NO}_{3}\right)_{3}$ and washing for $20 \mathrm{~min}$ in standard ASW. \#\#\#p<0.001 vs control; n.s, not significant $v s$ glutamate; ${ }^{* * *} \mathrm{p}<0.001$ $v s$ glutamate and control, $\mathrm{n}=20$.

Fig. 3. Percentage of hemolysis after $1 \mathrm{~h}$ of treatment with different doses of crude venom (c.v.). The control represents the hemolysis detected in untreated $0.05 \%$ erythrocytes suspensions in isotonic buffer. Venom concentration is reported as volume/volume percentage $(\mathrm{v} / \mathrm{v})$. Values are mean \pm s.e.m. of 20 independent experiments. \#\#\# p<0.001 vs control, ${ }^{* * *} \mathrm{p}<0.001$ vs $5 \% \mathrm{v} / \mathrm{v}$ c.v. and control.


2.25, n.s. vs glutamate, Fig. 2), with the notable exception of $\mathrm{La}\left(\mathrm{NO}_{3}\right)_{3}$ (nematocysts/probe: $16.46 \pm 2.62$, $\mathrm{p}<0.001$ vs glutamate, Fig. 2).

In order to assess whether the inhibitory effect of heavy metals on discharge was due to oxidative stress events, oral arms were pre-incubated for 20 min in standard ASW containing heavy metal salts and $0.1 \mathrm{mM}$ glutathione (GSH) or $1 \mathrm{mM}$ ascorbic acid as antioxidants. Then, the solution containing heavy metals and the antioxidant was removed and combined chemical-mechanical stimulation was applied as described above. Simultaneous treatment with an antioxidant failed to reduce the inhibitory activity of heavy metals on discharge response (data not shown).

Hemolytic assay

Fig. 3 reports the hemolytic activity of crude venom extracted from holotrichous isorhizas nematocysts on $0.05 \%$ human erythrocytes suspensions. Treatment of erythrocytes for $1 \mathrm{~h}$ at $37^{\circ} \mathrm{C}$ with crude venom induced a significant, dose-dependent hemolysis with respect to 
Tab. 1. Effect of individual heavy metals and their mixture on the hemolytic activity of 10 and/or $20 \%$ v/v Pelagia noctiluca crude venom (c.v.). Hemolysis percentages represent mean values obtained in at least 20 experiments. n.s., not significant vs control; ${ }^{* * *} \mathrm{p}<0.001$ vs $10 \% \mathrm{v} / \mathrm{v}$ c.v.; n.s.10, not significant vs 10\% v/v c.v.; \#\#\# p<0.001, \#\# p<0.01 vs $20 \%$ v/v c.v.; n.s.20, not significant vs $20 \%$ v/v c.v. Values for control, $10 \% \mathrm{v} / \mathrm{v}$ c.v. and $20 \% \mathrm{v} / \mathrm{v}$ c.v. referred to individual heavy metals are taken from Fig. 3.

\begin{tabular}{|c|c|c|c|}
\hline \multirow{4}{*}{$\begin{array}{c}\text { Individual } \\
\text { heavy metals }\end{array}$} & \multicolumn{3}{|c|}{$\%$ Hemolysis } \\
\hline & Control & $10 \% \mathrm{v} / \mathrm{v}$ c.v. & $20 \% \mathrm{v} / \mathrm{v}$ c.v. \\
\hline & & $45.63 \pm 1.15$ & $99 \pm 0.004$ \\
\hline & Heavy metals & $\begin{array}{c}\text { Heavy metals } \\
\text { and } 10 \% \mathrm{v} / \mathrm{v} \text { c.v. }\end{array}$ & $\begin{array}{c}\text { Heavy metals } \\
\text { and } 20 \% \mathrm{v} / \mathrm{v} \text { c.v. }\end{array}$ \\
\hline $2 \mathrm{mM} \mathrm{ZnCl}_{2}$ & $0.29 \pm 0.8$ n.s. & $5 \pm 1^{* * *}$ & $5.12 \pm 2.1$ \#\#\# \\
\hline $5 \mathrm{mM} \mathrm{ZnCl}_{2}$ & $0.55 \pm 0.9$ n.s. & $3 \pm 0.9 * * *$ & $8.13 \pm 0.8$ \#\#\# \\
\hline $10 \mathrm{mM} \mathrm{ZnCl}_{2}$ & $1.73 \pm 1.002$ n.s. & $2.5 \pm 0.8 * * *$ & $2.6 \pm 1$ \#\#\# \\
\hline $2 \mathrm{mMCdSO}_{4}$ & $1.5 \pm 0.3$ n.s. & $11.8 \pm 1.5^{* * *}$ & $9.5 \pm 2.5$ \#\#\# \\
\hline $5 \mathrm{mM} \mathrm{CdSO}_{4}$ & $1 \pm 0.2$ n.s. & $18.7 \pm 2.1 * * *$ & $37.6 \pm 3$ \#\#\# \\
\hline $10 \mathrm{mM} \mathrm{CdSO}_{4}$ & $1.74 \pm 0.1$ n.s. & $35.6 \pm 2 * * *$ & $29.8 \pm 1.8$ \#\#\# \\
\hline $2 \mathrm{mM} \mathrm{CoCl}_{2}$ & $5.95 \pm 2$ n.s. & $57.8 \pm 2$ n.s. 10 & $100 \pm 0.8$ n.s. 20 \\
\hline $5 \mathrm{mM} \mathrm{CoCl}_{2}$ & $2.51 \pm 0.8$ n.s. & 8 n.s.10 & $94.5 \pm 2$ n.s. 20 \\
\hline $10 \mathrm{mM} \mathrm{CoCl}_{2}$ & $3.77 \pm 1$ n.s. & $42.3 \pm 0.9$ n.s. 10 & $95.2 \pm 2$ n.s. 20 \\
\hline $2 \mathrm{mM} \mathrm{La}\left(\mathrm{NO}_{3}\right)_{3}$ & $9.12 \pm 2$ n.s. & $51 \pm 0.9$ n.s. 10 & $83.7 \pm 0.9$ n.s. 20 \\
\hline $5 \mathrm{mM} \mathrm{La}\left(\mathrm{NO}_{3}\right)_{3}$ & $10.55 \pm 1.9$ n.s. & $38 \pm 2.3 * * *$ & $41.6 \pm 4$ \#\#\# \\
\hline $10 \mathrm{mM} \mathrm{La}\left(\mathrm{NO}_{3}\right)_{3}$ & $11.84 \pm 1.5$ n.s. & $37.2 \pm 4 * * *$ & 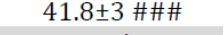 \\
\hline \multirow{3}{*}{$\begin{array}{l}\text { Heavy metals } \\
\text { mixture }\end{array}$} & & \multirow{5}{*}{$\begin{array}{l}\text { Heavy metals } \\
\text { and } 10 \% \mathrm{v} / \mathrm{v} \text { c.v. }\end{array}$} & $20 \%$ v/v c.v. \\
\hline & & & $84.6 \pm 5.4$ \\
\hline & Heavy metals & & $\begin{array}{l}\text { Heavy metals } \\
\text { and } 20 \% \mathrm{v} / \mathrm{v} \text { c.v. }\end{array}$ \\
\hline $1 \mathrm{mM}$ mixture & $9.9 \pm 2.9$ n.s. & & $88 \pm 7$ n.s. 20 \\
\hline $10 \mathrm{mM}$ mixture & $13.4 \pm 0.4$ n.s. & & $13.15 \pm 0.1$ \#\# \\
\hline
\end{tabular}

untreated erythrocytes (control). As shown, $5 \%$ and $10 \% \mathrm{v} / \mathrm{v}$ crude venom induced a $21.7 \pm$ $2 \%$ and $45.63 \pm 1.15 \%$ hemolysis respectively, while exposure to $20 \% \mathrm{v} / \mathrm{v}$ crude venom led to an almost complete hemolysis. Hemolysis obtained with $10 \%$ and $20 \% \mathrm{v} / \mathrm{v}$ crude venom was significantly higher with respect to that observed with $5 \% \mathrm{v} / \mathrm{v}$ crude venom $(\mathrm{p}<0.001)$. On this basis, to test for the possible effect of heavy metals on the hemolytic power of crude venom, $10 \%$ and $20 \% \mathrm{v} / \mathrm{v}$ venom concentrations were used and the $5 \% \mathrm{v} / \mathrm{v}$ venom concentration was excluded from the experimental design.

Incubation of erythrocyte suspensions with 2, 5 and $10 \mathrm{mM} \mathrm{ZnCl}_{2}, \mathrm{CdSO}_{4}, \mathrm{CoCl}_{2}$ or $\mathrm{La}\left(\mathrm{NO}_{3}\right)_{3}$ did not elicit significant hemolysis compared to untreated erythrocytes (control, Table 1).

Interestingly, addition of 2,5 and $10 \mathrm{mM} \mathrm{ZnCl}_{2}$ or $\mathrm{CdSO}_{4}$ to the erythrocyte suspensions significantly impaired the hemolytic activity of both 10 and $20 \% \mathrm{v} / \mathrm{v}$ crude venom $(\mathrm{p}<0.001$, Table 1). In contrast, 2,5 and $10 \mathrm{mM} \mathrm{CoCl}_{2}$ treatment did not affect the hemolytic activity of both 10 and $20 \% \mathrm{v} / \mathrm{v}$ crude venom (tab. 1 ). With regard to $\mathrm{La}\left(\mathrm{NO}_{3}\right)_{3}$ effect, 5 and $10 \mathrm{mM}$ $\mathrm{La}\left(\mathrm{NO}_{3}\right)_{3}$ significantly impaired the hemolytic activity of both 10 and $20 \% \mathrm{v} / \mathrm{v}$ crude venom ( $\mathrm{p}<0.001$, tab. 1), while $2 \mathrm{mM} \mathrm{La}\left(\mathrm{NO}_{3}\right)_{3}$ was ineffective (Table 1$)$.

Incubation of erythrocyte suspensions with quaternary mixtures of $\mathrm{ZnCl}_{2}, \mathrm{CdSO}_{4}, \mathrm{CoCl}_{2}$ and $\mathrm{La}\left(\mathrm{NO}_{3}\right)_{3}$ in equimolar concentrations (total concentration: 1 and $10 \mathrm{mM}$ ) did not elicit significant hemolysis compared to untreated erythrocytes (control, Table 1). The $10 \mathrm{mM}$ heavy metals mixture completely blunted the hemolytic activity of $20 \% \mathrm{v} / \mathrm{v}$ crude venom, while the $1 \mathrm{mM}$ heavy metals mixture was ineffective (Table 1).

\section{Discussion}

Metal pollution is a threat for ecological environment, affecting animals homeostasis at tissue and cell level [34]. Due to the detrimental effects of the heavy metals, research has focused on monitoring their concentrations and toxic effects in marine environments and organisms. In this regard, amongst marine vertebrates, fishes have been often used as bioindicators [35], while, among invertebrates, Cnidaria have not been exhaustively explored yet.

As described by Tarrant [36], pollutants may be internalized by Cnidaria by either uptake, ingestion or contact with chemicals contained in marine waters, suggesting a possible use of these specimens as a model for ecotoxicological investigations and biomonitoring of 
marine water quality. An interesting example is given by hydras, sensitive to metals and other environmental toxicants, including cadmium, zinc and butyltin [36-38].

The present investigation would propose the jellyfish Pelagia noctiluca as a novel model to verify and quantify heavy metals environmental pollution and bioaccumulation. This can be achieved by evaluating the effectiveness of nematocysts discharge and toxins delivered upon discharge, two features that, along with the cell volume regulation response under anisosmotic conditions, have allowed Cnidaria survival through the ages $[1,15,30,39]$. What reported here completes our previous study on cell volume regulation of Pelagia noctiluca nematocytes [19], in an attempt to describe the homeostasis of this jellyfish in altered environmental conditions, i.e. in the presence of heavy metals. In this light, we tried to add novel information on the effect of metals on both nematocysts discharge and hemolytic power of crude venom. Hence, the same metals chosen for cell volume regulation investigations (i.e. Zinc, Cadmium, Cobalt and Lanthanum [19]) have been used. These pollutants are not only harmful for marine ecosystems, but are also of major concern for the human health [40,41].

With regard to cell volume regulation capability, we previously demonstrated [19] that exposure of isolated nematocytes to heavy metals inhibits cell membrane transport systems underlying the regulatory volume decrease (RVD), the ubiquitous homeostatic response enabling cells [42,43], including nematocytes [44], to counteract the osmolarity changes in the external medium. With regard to the hemolytic activity of crude venom extracted from Pelagia noctiluca nematocysts, Marino et al. [22] provided evidences of the inhibitory effect of divalent cations (1-10 mM), while nematocysts discharge and effectiveness of delivered toxins have not been considered yet to test heavy metal toxicity.

Here we show that a 20 minutes exposure of oral arms to heavy metal salts like $\mathrm{ZnCl}_{2}$, $\mathrm{CdSO}_{4}, \mathrm{CoCl}_{2}$, or $\mathrm{La}\left(\mathrm{NO}_{3}\right)_{3}$, in concentrations similar to what reported elsewhere [22] and in line with concentrations measured in different basins [45, 46], dramatically impaired nematocysts discharge. This inhibitory effect seems to be in most cases - but not always reversible, since extensive washing of oral arms with artificial sea water after exposure to heavy metals completely restored discharge response, with the exception of $\mathrm{La}\left(\mathrm{NO}_{3}\right)_{3}$. This observation is in line with what described by Morabito et al. [19], observing a reduced RVD response in isolated nematocytes of Pelagia noctiluca treated for $20 \mathrm{~min}$ with heavy metals. Inhibition of discharge response by metals has been demonstrated for the first time by Santoro and Salleo [47] and Salleo et al. [48] by using gadolinium, a metal of the lanthanide series of the periodic table and a specific $\mathrm{Ca}^{2+}$ channel blocker, thus defining discharge as a $\mathrm{Ca}^{2+}$-dependent phenomenon. Therefore, it is possible to hypothesize that heavy metals may similarly act by blocking ion channels involved in the transduction pathway triggering discharge. Moreover, Souza et al. [49] reported that $\mathrm{Ca}^{2+}$ channel blockers, such as nifedipine and verapamil, reduced cadmium uptake in several cell types, supporting the conclusion that cadmium may compete with $\mathrm{Ca}^{2+}$ for the uptake through $\mathrm{Ca}^{2+}$ channels. The presence of heavy metals in the extracellular environment may thus interfere with $\mathrm{Ca}^{2+}$ signaling and block discharge triggering.

Although discharge control has not been totally elucidated, some authors proposed that an osmotic influx of water, following ion uptake through channels, may represent the event underlying one of the first stages through which discharge normally occurs, i.e. an osmotic swelling of the nematocyte leading to delivery of tubule and toxins. On this basis, we suggest that heavy metals may affect discharge by impairing ion fluxes via membrane transport systems. As stated above, that ion transport in Pelagia noctiluca nematocytes is affected by heavy metals has been already shown [20], pointing out that heavy metals compromise ion fluxes through channels and/or co-transporters needed to perform RVD in isolated nematocytes. On a cellular level, the interaction of heavy metals with cell membrane transport mechanisms is the basis for their effect on biological systems. Examples of this interaction are given by Foulkes [50], describing the internalization of metals inside the cell, and Yu et al. [51], describing an alteration of the activity of epithelial sodium channels $(\mathrm{ENaC})$ following divalent heavy metals exposure. 
Our findings also show that the treatment of oral arms with heavy metals in the presence of GSH as antioxidant compound, did not protect the tissue from discharge inhibition. This result would indicate that heavy metals do not inhibit discharge response via an oxidative damage at tissue level. In contrast with this evidence, other authors described that metals may cause reactive oxygen species (ROS) production and, in turn, cell and DNA damage, impaired mitochondrial respiration, cell cycle arrest and apoptosis in various biological models [52-55]. Hence, the overall consideration is that the effect of metals such as Zinc, Cadmium, Cobalt and Lanthanum on biological substrates may be heterogeneous, also owing on the variety of the in vitro models used for toxicity assays [38, 56-58].

To further verify whether heavy metals totally compromise the defensive response of Cnidaria, that is based not only on nematocysts discharge, but also on effectiveness of delivered toxins, the hemolytic activity of crude venom from Pelagia noctiluca has been evaluated. Here we demonstrate that heavy metals, with the exception of Cobalt, substantially reduce the hemolytic power of crude venom extracted from nematocysts. The concentration and time of exposure of erythrocytes to metals allowed to exclude any direct hemolytic effect of Cadmium, Cobalt, Zinc and Lanthanum (see Tabele 1, control). The concentrations used (2-10 mM) were similar to those already employed by Marino et al. [22] for testing the hemolytic activity of Pelagia noctiluca crude venom in the presence of divalent cations or osmotic protectants.

In metal-exposed erythrocytes, oxidative damage of erythrocyte membrane leads to a reduction in membrane fluidity and increase in membrane fragility [59]. Accordingly, Hernández-García et al. [60] have recently described that heavy metals may induce hemolysis by lipoperoxidation. These observations differ to the results of our experiments, where no direct metal-dependent hemolysis was observed. We envision indeed that heavy metals may alter crude venom components, substantially preventing their hemolytic power. Accordingly, evidence exists that cations may affect the protein structure of toxins. In particular, previous studies have shown that, in venom of the jellyfish Carybdea marsupialis, $\mathrm{Ca}^{2+}$ induced a significant decrease in hemolytic activity [12]. Moreover, our previous results [22] showed that metal ions like $\mathrm{Ba}^{2+}$ and $\mathrm{Cu}^{2+}$ block the hemolytic activity of Pelagia noctiluca crude venom.

Testing the effect of heavy metals mixtures instead of the single components may be a more realistic representation of sea water pollution $[35,45]$. Therefore, a further set of experiments has been carried out to explore the effect of quaternary heavy metals mixtures on the hemolytic power of Pelagia noctiluca crude venom. A $10 \mathrm{mM}$ (total concentration) Cadmium, Cobalt, Zinc and Lanthanum mixture completely impaired the hemolytic activity of crude venom, probably due to the presence of individual concentrations of Cadmium and Cobalt with maximal activity (Table 1). This observation leads to exclude possible antagonistic effects of the single components within the mixture. Conversely, a $1 \mathrm{mM}$ (total concentration) mixture was completely ineffective, leading to exclude possible synergistic effects in our system, in agreement with previous findings on ternary and quaternary mixtures [35].

A mechanism of action suggested for many Cnidarian toxins [61], including Pelagia noctiluca [22], is the insertion of toxin molecules into the plasma membrane, the first phase of pore formation finally leading to colloid osmotic lysis of target cells. In this regard, the latter authors reported that the mechanism of toxin action mainly depends on poreforming into the membrane of cell target rather than oxidative damage, since GSH, cysteine and ascorbic acid did not impair the hemolytic power. Based on these observations, an intriguing hypothesis is that the interaction of metals with cell membrane [50] or crude venom components may reduce the hemolytic activity of venom by impairing the binding and insertion of pore-forming toxins in the membrane of target cells. Accordingly, Miyake et al. [62] explained the inhibitory effect of divalent cations upon Vibrio metschnikovii cytolysin by changes in the erythrocytes membrane fluidity, so that pore formation due to the toxin was impaired, while, on the other hand, Iwase et al. [63] suggested that extracellular $\mathrm{Ca}^{2+}$ may accelerate the rate of removal of the toxin by endocytosis. 


\section{Conclusion}

Taken together, our findings show that nematocysts discharge response and effectiveness of toxins contained in the crude venom of the jellyfish Pelagia noctiluca are dramatically affected by short-term exposure to an external medium containing heavy metals, leading thus to reasonably hypothesize that the homeostasis of the entire animal may be compromised by these pollutants. Specifically, the strongest inhibition of nematocysts discharge was observed with Cadmium and Lanthanum and was irreversible with the latter, while Zinc and Cadmium were most effective in reducing the hemolytic activity of the crude venom.

Based on these evidences, we suggest that the jellyfish Pelagia noctiluca constitutes a good model for monitoring heavy metals environmental pollution and bioaccumulation. Evaluating Pelagia noctiluca physiological functions following pollutants exposure may provide novel contribution to eco-toxicological investigations. In this regard, further studies are warranted to elucidate the precise molecular mechanism of heavy metals in reducing nematocysts discharge and effectiveness of toxins and to monitor the effect of a long-term exposure to heavy metals on the homeostatic functions of this species.

\section{Disclosure Statement}

The authors have no conflict of interest to declare.

\section{References}

1 Fautin DG: Structural diversity, systematics, and evolution of cnidae. Toxicon 2009;54:1054-1064.

2 Ozbeck S, Balasubramanian PG, Holstein TW: Cnidocyst structure and the biomechanics of discharge. Toxicon 2009;54:1038-1045.

-3 Holstein T, Tardent P: An ultrahigh-speed analysis of exocytosis: nematocyst discharge. Sciences 1984;223:830-833.

4 Salleo A: Discharge mechanism of the nematocysts of Pelagia noctiluca; in Bolis L, Zadunaisky J, Gilles R (eds): Toxins and Drugs of Marine Animals to Pollutants, Springer Verlag: Berlin, Heidelberg, 1984, pp 6368.

5 Morabito R, Marino A, La Spada G: Nematocytes activation in Pelagia noctiluca (Cnidaria, Scyphozoa) oral arms. J Comp Physiol A Neuroethol Sens Neural Behav Physiol 2012;198:419-426.

-6 Watson GM, Hessinger DA: Cnidocyte mechanoreceptors are tuned to the movements of swimming prey by chemoreceptors. Science 1989;243:1589-1591.

7 Watson GM, Hessinger DA: Receptors for N-acetylated sugars may stimulate adenylate cyclase to sensitize and tune mechanoreceptors involved in triggering nematocysts discharge. Exp Cell Res 1992;198:8-16.

8 Mire-Thibodeaux P, Watson GM: Mechanotransduction of hair bundles arising from multicellular complexes in anemones. Hearing Res 1997;113:224-234.

-9 Ozacmak VH, Thorington GU, Fletcher WH, Hessinger DA: N-Acetylneuraminic acid (NANA) stimulates in situ cyclic AMP production in tentacles of sea anemone (Aiptasia pallida): possible role in chemosensitization of nematocyst discharge. J Exp Biol 2001;204:2011-2020.

10 Hidaka M: Mechanism of nematocyst discharge and its cellular control. Adv Comp Env Physiol 1993;15:4576.

-11 Scappaticci AA Jr, Kahn F, Kass-Simon G: Nematocyst discharge in Hydra vulgaris: Differential responses of desmonemes and stenoteles to mechanical and chemical stimulation. Comp Biochem Physiol A Mol Integr Physiol 2010;157:184-191.

-12 Rottini G, Gusmani L, Parovel E, Avian, Patriarca P: Purification and properties of a cytolytic toxin in venom of the jellyfish Carybdea marsupialis. Toxicon 1995;33:315-326.

13 Radwan FF, Gershwin L, Burnett JW: Toxinological studies on the nematocyst venom of Chrysaora achlyos. Toxicon 2000;38:1581-1591.

14 Monroy-Estrada HI, Segura-Puertas L, Galvan-Arzate S, Santamaria A, Sànchez-Rodrìguez J: The crude venom from the sea anemone Stichodactyla helianthus induces haemolysis and slight peroxidative damage in rat and human erythrocytes. Toxicol in Vitro 2007;21:398-402. 
15 Frazão B, Vasconcelos V, Antunes A: Sea anemone (Cnidaria, Anthozoa, Actiniaria) toxins: an overview. Mar Drugs 2012;10:1812-1851.

16 Pereira P, Seymour JE: In vitro effects on human heart and skeletal cells of the venom from two cubozoans, Chironex fleckeri and Carukia barnesi. Toxicon 2013;76:310-315.

17 Mariottini GL, Pane L: Cytotoxic and cytolytic cnidarian venoms. A review on health implications and possible therapeutic applications. Toxins 2013;6:108-151.

- 18 Bruschetta G, Impellizzeri D; Morabito R, Marino A, Ahmad A, Spanò N, La Spada G, Cuzzocrea S, Esposito E: Pelagia noctiluca (Scyphozoa) crude venom injection elicits oxidative stress and inflammatory response in rats. Mar Drugs special issue “Bioactive Compounds from Marine Invertebrates" 2014;12:2182-2204.

19 Morabito R, Marino A, La Spada G: Heavy metals affect Regulatory Volume Decrease (RVD) in nematocytes isolated from the jellyfish Pelagia noctiluca. Comp Biochem Physiol A 2013;165:199-206.

20 Morabito R, Marino A, Lauf PK, Adragna NC, La Spada G: Sea water acidification affects osmotic swelling, Regulatory Volume Decrease and discharge in nematocytes of the jellyfish Pelagia noctiluca. Cell Physiol Biochem 2013;32:77-85.

21 Marino A, Crupi R, Rizzo G, Morabito R, Musci G, La Spada G: The unusual toxicity and stability properties of crude venom from isolated nematocysts of Pelagia noctiluca (Cnidaria, Scyphozoa). Cell Mol Biol 2007;53:994-1002.

-22 Marino A, Morabito R,Pizzata T, La Spada G: Effect of various factors on Pelagia noctiluca (Cnidaria, Scyphozoa) crude venom-induced haemolysis. Comp Biochem Physiol A 2008;151:144-149.

23 Marino A, Morabito R, Pizzata T, La Spada G: Effect of crude venom from nematocysts of Pelagia noctiluca (Scyphozoa) on spread discharge of acontia of Calliactis parasitica (Anthozoa). Chem Ecol 2008;24:9-17.

24 Marino A, Morabito R, La Spada G: Factors altering the haemolytic power of crude venom from Aiptasia mutabilis (Anthozoa) nematocysts. Comp Biochem Physiol Part A 2009;152:418-422.

25 Marino A, Di Paola R, Crisafulli C, Mazzon E, Morabito R, Paterniti I, Galuppo M, Genovese T, La Spada G, Cuzzocrea S: Protective effect of melatonin against the inflammatory response elicited by crude venom from isolated nematocysts of Pelagia noctiluca (Cnidaria, Scyphozoa). J Pineal Res 2009;47:56-69.

26 Morabito R, Marino A, Romano P, Rigano C, La Spada G: Sulphate and Chloride-Dependent Potassium Transport in Human Erythrocytes are Affected by Crude Venom from Nematocysts of the Jellyfish Pelagia noctiluca. Cell Physiol Biochem 2013;32:S86-95.

27 Dossena S, Nofziger C, Morabito R, Adragna NC, Paulmichl M: Synopsis of the $48^{\text {th }}$ annual meeting of the Lake Cumberland Biological Transport Group and the second biannual meeting of the Pendrin Consortium. Cell Physiol Biochem. 2013;32:S1-13.

28 Rosa S, Pansera M, Granata A, Guglielmo L: Interannual variability, growth, reproduction and feeding of Pelagia noctiluca (Cnidaria: Scyphozoa) in the Strait of Messina (Central Mediterranean Sea): Linkages with temperature and diet. J Mar Syst 2013;111-112:97-107.

29 Salleo A, La Spada G, Falzea G, Denaro MG: Discharging effectiveness of lyotropic anions on nematocysts of Pelagia noctiluca. Mol Physiol 1983;6:19-26.

-30 Marino A, Morabito R, La Spada G, Adragna NC, Lauf PK: Evidence for aquaporin-mediated water transport in nematocytes of the jellyfish Pelagia noctiluca. Cell Physiol Biochem 2011;28:1211-1218.

- 31 Mariottini GL, Pane L: Mediterranean jellyfish venoms: a review on scyphomedusae. Mar Drugs 2010;8:1122-1152.

32 Mariscal RN: Nematocysts; in Muscatine L, Lenhoff HL (eds): Coelenterate Biology: Reviews and New Perspective, Academy Press: New York, London, 1974, pp 129-178.

33 Thorington GU, Hessinger DA: Efferent mechanisms of discharging cnidae: I. Measurements of intrinsic adherence of cnidae discharged from tentacles of the sea anemone, Aiptasia pallida. Biol Bull 1996;190:125-138.

34 Waalkes MP: Cadmium carcinogenesis. Mutat Res 2003;533:107-120.

35 Xu X, Li Y, Wang Y, Wang Y: Assessment of toxic interactions of heavy metals in multi-component mixtures using sea urchin embryolarval bioassay. Toxicol In Vitro 2011;25:294-300.

-36 Tarrant A: Hormonal signaling in Cnidarians: do we understand the pathways well enough to know whether they are being disrupted? Ecotoxicology 2007;16:5-13.

- 37 Harter VL, Matthews RA: Acute and chronic toxicity test methods for Nematostella vectensis Stephenson. Bull Environ Contam Toxicol 2005;74:830-836.

38 Holdway DA, Lok K, Semaan M: The acute and chronic toxicity of cadmium and zinc to two Hydra species. Environ Toxicol 2001;16:557-565. 


\section{Cellular Physiology Cell Physiol Biochem 2014;34:244-254 and Biochemistry

39 Beckmann A, Özbek S: The nematocyst: a molecular map of the cnidarian stinging organelle. Int J Dev Biol 2012;56:577-582.

40 Jomova K, Valko M: Advances in metal-induced oxidative stress and human disease. Toxicology 2011;283:65-87.

-41 Zhao H, Hong J, Yu X, Zhao X, Sheng L, Ze Y, Sang X, Gui S, Sun Q Wang L, Hong F: Oxidative stress in the kidney injury of mice following exposure to lanthanides trichloride. Chemosphere 2013;93:875-884.

42 Hoffmann EK, Pedersen SF: Cell volume homeostatic mechanisms: effectors and signaling pathways. Acta Physiol 2011;202:465-485.

43 Lang F: Mechanisms and significance of cell volume regulation. J Am Coll Nutr. 2007;26:613S-623S.

-44 La Spada G, Biundo T, Nardella R, Meli S: Regulatory volume decrease in nematocytes isolated from acontia of Aiptasia diaphana. Cell Mol Biol 1999;45:249-258.

45 Morillo J, Usero J, Gracia I: Heavy metal distribution in marine sediments from the southwest coast of Spain. Chemosphere 2004;55:431-442.

-46 Adamo P, Arienzo M, Imperato M, Naimo D, Nardi G, Stanzione D: Distribution and partition of heavy metals in surface and sub-surface sediments of Naples city port. Chemosphere 2005;61:800-809.

47 Santoro G, Salleo A: The discharge in situ of nematocysts of the acontia of Aiptasia mutabilis is a $\mathrm{Ca}^{2+}$ induced response. J Exp Biol 1991;156:173-185.

48 Salleo A, La Spada G, Barbera R: Gadolinium is a powerful blocker of the activation of nematocysts of Pelagia noctiluca. J Exp Biol 1994;187:201-206.

49 Souza V, Bucio L, Gutiérrez-Rui MC: Cadmium uptake by a human hepatic cell line (WRL-68 cells). Toxicology $1997 ; 120: 215-220$.

50 Foulkes EC: Transport of toxic metal across cell membranes. Proc Soc Exp Biol Med 2000;223:234-240.

51 Yu L, Douglas CE, Helms MN: Effect of divalent heavy metals on epithelial Na+ channels in A6 cells. Am J Physiol Renal Physiol 2007;293:236-244.

-52 Yang PM, Chiu SJ, Lin LY: Differential effects of salen and manganese-salen complex (EUK-8) on the regulation of cellular Cadmium uptake and Toxicity. Toxicol Sciences 2005;85:551-559.

53 Nemmiche S, Chabane-Sari D, Guiraud P: Role of alpha-tocopherol in cadmium-induced oxidative stress in Wistar rat's blood, liver and brain. Chem Biol Interact 2007;170:221-230.

54 Gobe G, Crane D: Mitochondria, reactive oxygen species and cadmium toxicity in the kidney. Toxicol Lett 2010;198:49-55.

-55 Stępkowski TM, Brzóska K, Kruszewski M: Silver nanoparticles induced changes in the expression of NF- $\mathrm{kB}$ related genes are cell type specific and related to the basal activity of NF-кB. Toxicol in Vitro 2014;28:473478.

-56 Remyla SR, Ramesh M, Sajwan KS, Senthil Kumar K: Influence of zinc on cadmium induced haematological and biochemical responses in a freshwater teleost fish Catla catla. Fish Physiol Biochem 2008;34:169-174.

57 Singh D, Nath K, Trivedi SP, Sharma YK: Impact of copper on haematological profile of freshwater fish, Channa punctatus. J Environ Biol 2008;29:253-257.

-58 Gurbay A: Protective effect of zinc chloride against cobalt chloride-induced cytotoxicity on Vero cells: preliminary results. Biol Trace Elem Res 2012;148:110-116.

59 Kumar A, Ali M, Pandey BN, Hassan PA, Mishra KP: Role of membrane sialic acid and glycophorin protein in thorium induced aggregation and hemolysis of human erythrocytes. Biochimie 2010;92:869-879.

-60 Hernández-García A, Romero D, Gómez-Ramírez P, María-Mojica P, Martínez-López E, García-Fernández AJ: In vitro evaluation of cell death induced by cadmium, lead and their binary mixtures on erythrocytes of Common buzzard (Buteo buteo). Toxicol In Vitro 2014;28:300-306.

61 Edwards LP, Whitter E, Hessinger DA: Apparent membrane pore-formation by Portuguese Man-of-war (Physalia physalis) venom in intact cultured cells. Toxicon 2002;40:1299-1305.

62 Miyake M, Honda T, Miwatani T: Effect of divalent cations and saccharides on Vibrio metschnikovii cytolysininduced hemolysis of rabbit erythrocytes. Infect Immun 1989;57:158-163.

63 Iwase M, Lally ET, Berthold P, Korchak HM, Taichman SN: Effects of cations and osmotic protectants on cytolytic activity of Actinobacillus actynomycetemcomitans Leukotoxin. Infect Immun 1990;58:1782-1788. 